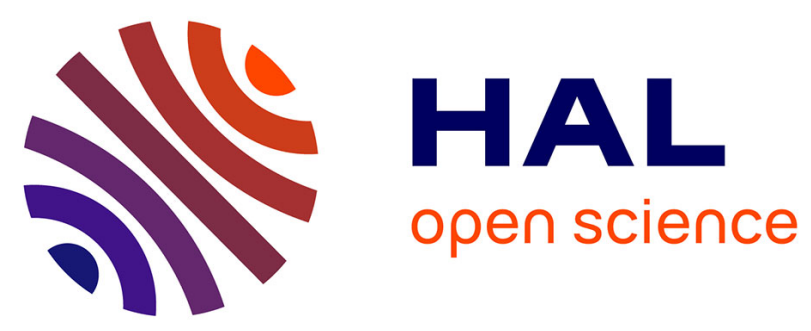

\title{
Long-range transport of continental radon in subantarctic and antarctic areas
}

Georges Polian, Gerard Lambert, Benedicte Ardouin, Alain Jegou

\section{To cite this version:}

Georges Polian, Gerard Lambert, Benedicte Ardouin, Alain Jegou. Long-range transport of continental radon in subantarctic and antarctic areas. Tellus B - Chemical and Physical Meteorology, 1986, 38 (3-4), pp.178-189. 10.3402/tellusb.v38i3-4.15126 . hal-03541045

\section{HAL Id: hal-03541045 \\ https://hal.science/hal-03541045}

Submitted on 24 Jan 2022

HAL is a multi-disciplinary open access archive for the deposit and dissemination of scientific research documents, whether they are published or not. The documents may come from teaching and research institutions in France or abroad, or from public or private research centers.
L'archive ouverte pluridisciplinaire HAL, est destinée au dépôt et à la diffusion de documents scientifiques de niveau recherche, publiés ou non, émanant des établissements d'enseignement et de recherche français ou étrangers, des laboratoires publics ou privés. 


\section{Tellus B: Chemical and Physical Meteorology}

\section{Long-range transport of continental radon in subantarctic and antarctic areas}

\section{Georges Polian, Gerard Lambert, Benedicte Ardouin \& Alain Jegou}

To cite this article: Georges Polian, Gerard Lambert, Benedicte Ardouin \& Alain Jegou (1986) Long-range transport of continental radon in subantarctic and antarctic areas, Tellus B: Chemical and Physical Meteorology, 38:3-4, 178-189, DOI: 10.3402/tellusb.v38i3-4.15126

To link to this article: https://doi.org/10.3402/tellusb.v38i3-4.15126

$$
\begin{aligned}
& \text { (c) } 1986 \text { The Author(s). Published by Taylor \& } \\
& \text { Francis. }
\end{aligned}
$$

曲 Published online: 18 Jan 2017.

Submit your article to this journal

LII Article views: 147

Q View related articles $₫$

4 Citing articles: 2 View citing articles 준 


\title{
Long-range transport of continental radon in subantarctic and antarctic areas
}

\author{
By GEORGES POLIAN*, GERARD LAMBERT, BENEDICTE ARDOUIN and ALAIN \\ JEGOU*, Centre des Faibles Radioactivites, Centre National de la Recherche Scientifique, Gif-sur-Yvette, \\ 91190 , France
}

(Manuscript received October 10, 1985; in final form April 17, 1986)

\begin{abstract}
Gaseous $\mathrm{Rn}-222$, a daughter product of $\mathrm{U}-238$, is injected into the atmosphere from the surface of continents. Its atmospheric cycle is particularly simple since it disappears only by radioactive decay (half-life 3.8 days). Radon measurements obtained over more than 15 years in remote stations in Antarctic and Subantarctic areas generally give concentrations as low as 0.1 to $2 \mathrm{pCi} \cdot \mathrm{m}^{-3}$. However, we have shown the existence of sharp increases of concentrations reaching 3 to $30 \mathrm{pCi} \cdot \mathrm{m}^{-3}$ called "radonic storms". Owing to the negligible degassing of radon from the sea surface, such peaks are accounted for by long-range transport from remote continents (mainly South Africa) over Southern Indian and Antarctic oceans, with transit times ranging from 1.5 to 7 days and very low dilution factors of the order of 3 to 7 . This airmass transport is related to warm sectors of cyclonic systems passing over South Africa and around the Antarctic continent.
\end{abstract}

\section{Introduction}

The concentration of atmospheric trace elements in remote areas results from their local production as well as long-range transport from their major sources. This is particularly true at Subantarctic islands where most of the trace elements present in the air can either be produced locally by the soil of the island or the ocean surface, as well as transported from remote continents.

An approach to the long-range transport consists in computing air mass trajectories by using the classical method of geostrophic winds, or isobaric, isentropic and actual trajectories as described for instance by Danielsen (1961) and Petersen and Uccellini (1979). Such calculations are particularly difficult in the Southern Hemisphere where meteorological data are scarce. Moreover, the hypothesis of adiabatic trajectories in the lower troposphere is questionable.

For these reasons, the use of continental tracers, for which sources, transport and dilution

\footnotetext{
* Also ORSTOM-TAAF, Paris
}

could be known, should be particularly fruitful in Antarctic and Subantarctic areas. During the last 25 years, the radon isotopes 220 and 222 have been frequently utilized for this purpose (Fontan et al., 1962; Lambert and Polian, 1963; Nguyen et al., 1967; Lambert et al., 1970 and 1972; Larson et al., 1972; Wilkniss et al., 1974; Nguyen et al., 1975; Turekian et al., 1977; Larson and Bressan, 1978; Rangarajan et al., 1979; Lambert et al., 1982).

Radon concentration has been monitored at French Antarctic and Subantarctic stations since 1960 (Fig. 1). The aim of this paper is to relate the measured radon concentrations to the transport processes of continental materials and specifically the transit times and dilutions involved.

\section{Radon isotopes 222 and 220 in the atmosphere}

The radon isotopes 222 and 220 are decay products of U-238 and Th-232 respectively. Their decay series are shown in Fig. 2. Rn-222 is injected into the atmosphere essentially from the 


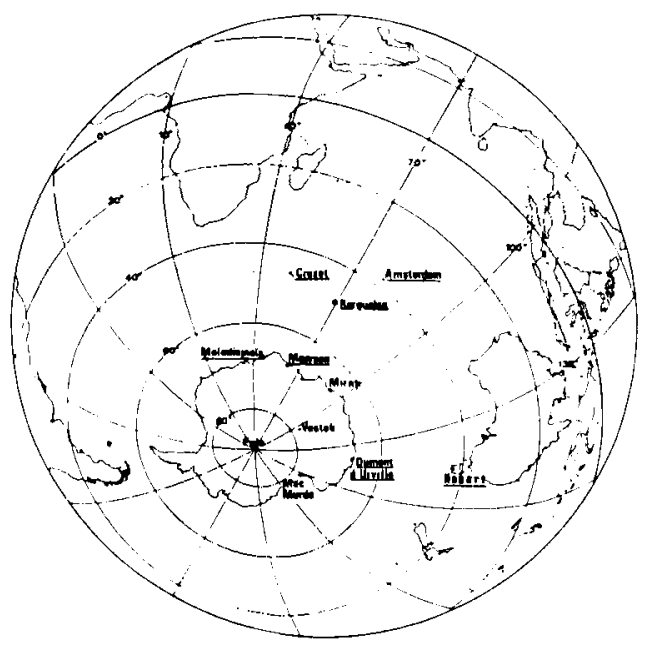

Fig. I. Stations in Antarctica and subantarctic areas. The stations mentioned in the paper are underlined. surface of continents, at a mean rate of approximately 0.7 atoms $\mathrm{cm}^{2} \cdot \mathrm{s}^{-1}$ (Lambert et al., 1982). In contrast, the degassing rate of the sea surface is about 100 times less (Broeker et al., 1967; Hoang and Servant, 1972; Wilkening and Clements, 1975). Therefore it is clear that $R n-222$ is a good tracer of continental materials.

$\mathbf{R n}-222$ is a noble gas which disappears from the atmosphere only by radioactive decay with a 3.8 day half-life (5.5 day mean life). Its typical concentration in the continental atmosphere at ground level is of the order of 80 to $200 \mathrm{pCi} \cdot \mathrm{m}^{-3}$ (Lambert et al., 1982). This concentration decreases over the oceans both by radioactive decay and by dilution down to values of the order of 0.5 $\mathrm{pCi} \cdot \mathrm{m}^{-3}$ which are characteristic of a "pure marine atmosphere".

The Rn-220 ("Thoron") half-life is only $54 \mathrm{~s}$. However its daughter $\mathrm{Pb}-212$ (ThB) has a $10.6 \mathrm{~h}$ half-life and it is therefore possible to trace the
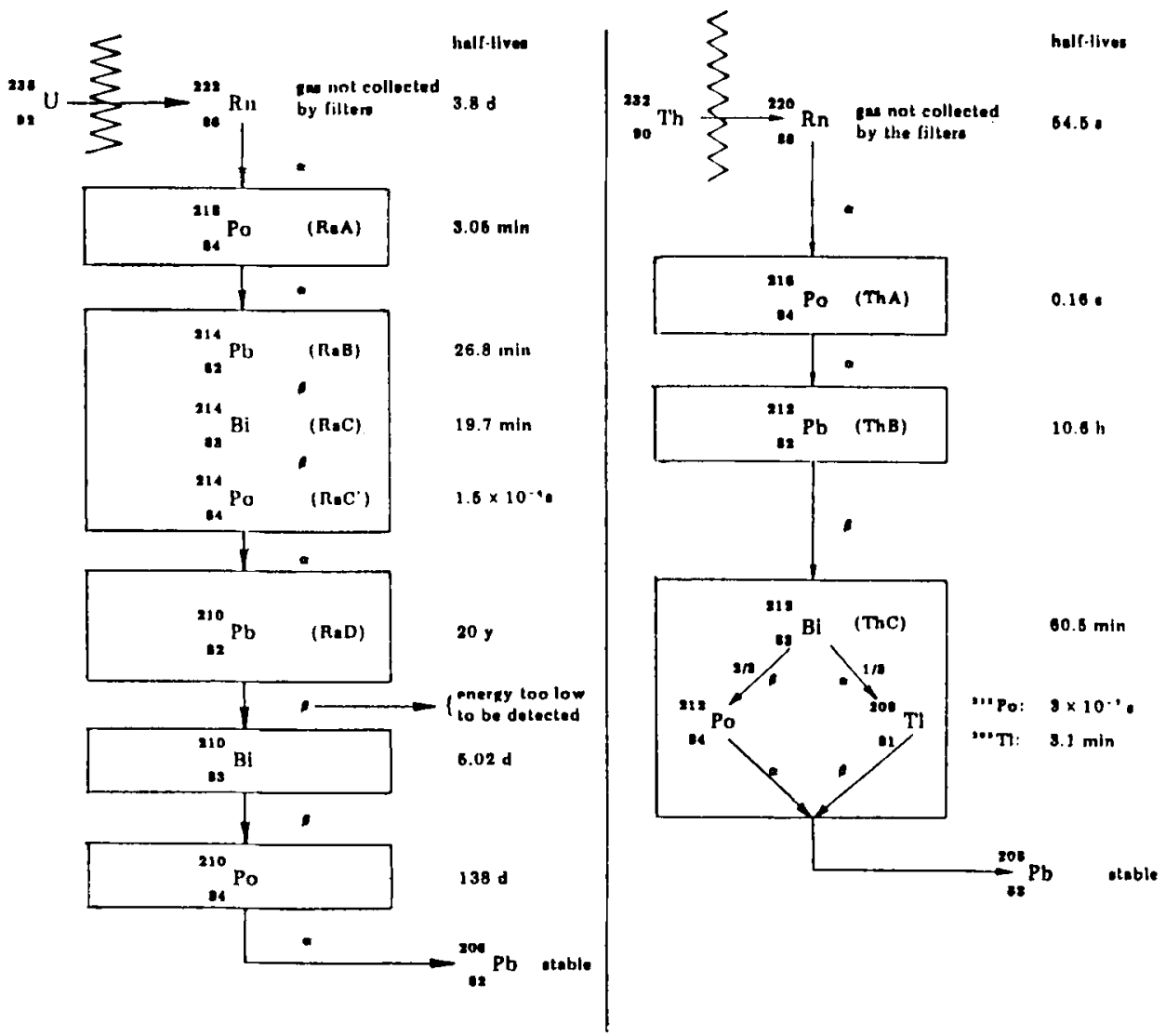

Fig. 2. Rn-222 and 220 decay series.

Tellus 38B (1986), 3-4 
aerosol particles on which it is fixed. The marine source of these nuclides can be considered as totally negligible, consequently the $\mathrm{Pb}-212$ measured on a Subantarctic island cannot be attributed to any marine or remote continental source but is only due to the local outgassing from the island's soil. Therefore by comparing the Rn222 and $\mathrm{Pb}-212$ concentrations at a Subantarctic station, we can distinguish between variations accounted for by changes in the local atmospheric eddy diffusion, or in long-range transport from remote continents. The measurement technique consists of filtering the atmospheric aerosols and measuring their alpha radioactivity versus time. The study of the activity decrease permits one to distinguish between $\mathrm{Rn}-222$ and $\mathrm{Pb}-212$ daughters and finally measurement of both the $\mathrm{Rn}-222$ and 220 concentrations (see Appendix).

\section{Long-range transport of Rn-222 over the subantarctic ocean}

The atmospheric concentration of $\mathrm{Rn}-222$ at sea level in the 3 stations Crozet, Kerguelen and Amsterdam Island (see Fig. 1) is generally between 0.2 and $1.5 \mathrm{pCi} \cdot \mathrm{m}^{-3}$. However, the main feature of the concentration record is the existence of rapid and sharp variations that we have called "Radonic Storms" (Lambert et al., 1970). During such an event, the $\mathrm{Rn}-222$ concentration can increase in about $4 \mathrm{~h}$ from less than $1 \mathrm{pCi} \cdot \mathrm{m}^{-3}$ up to $4-10 \mathrm{pCi} \cdot \mathrm{m}^{-3}$ and exceptionally to $20 \mathrm{pCi} \cdot \mathrm{m}^{-3}$ at Kerguelen and Amsterdam Island and $40 \mathrm{pCi} \cdot \mathrm{m}^{-3}$ at Crozet Island, and then decrease again to normal values, 2 to $6 \mathrm{~h}$ later (see Figs. 3, 4).

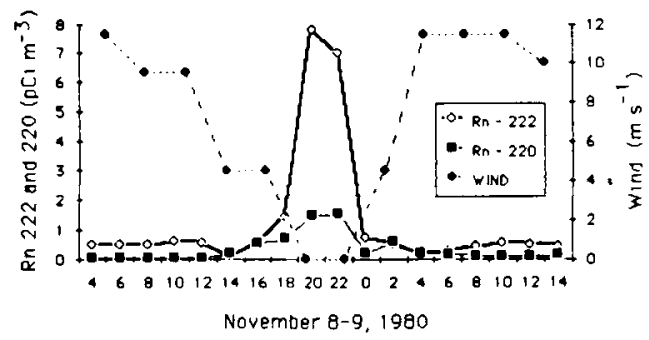

Fig. 3. Example of a Rn-222 peak observed at Kerguelen Island in correlation with $\mathrm{Rn}-220$. Both are due to local $R n$ exhausts by very low wind.

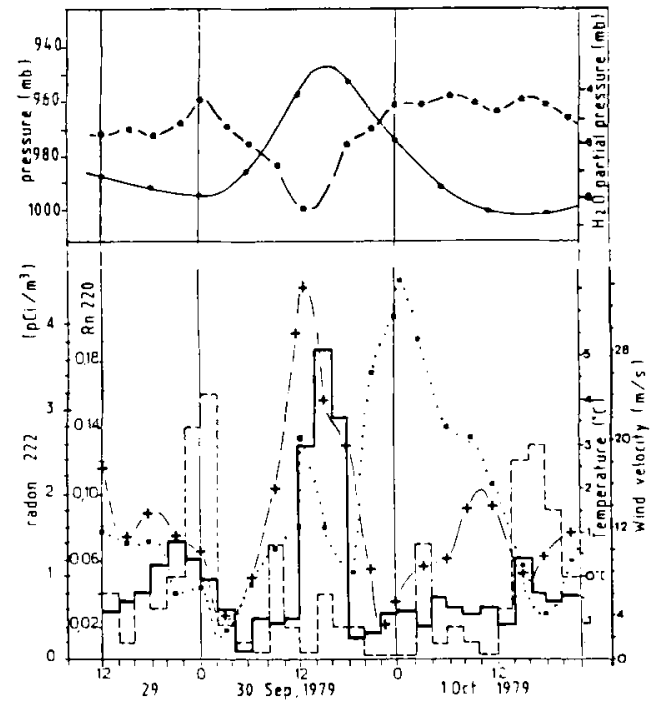

Fig. 4. Example of a $\mathrm{Rn}-222$ peak observed at Kerguelen Island by strong wind and very low Rn-220 activity. — Radon 222. _- Radon 220. -+-+- Air temperature. $\cdots \square \cdots$ Wind velocity. - * Atmospheric pressure. - - Water vapor partial pressure.

Some radonic storms are due to the local production of radon: they are observed for wind speed less than $5 \mathrm{~m} \cdot \mathrm{s}^{-1}$ and meteorological conditions corresponding to a low atmospheric eddy diffusion (Fig. 3). The figure also shows the existence of a peak of $\mathrm{Rn}-220$ (Thoron) which occurred at the same time, and which was definitely of local origin. In contrast, a large number of $\mathrm{Rn}-222$ peaks are observed during strong winds and associated with low concentrations of Rn-220 (Fig. 4). These can therefore be ascribed to continental air mass advection characterized by low dilution and a rather short transit time. It should be noted that owing to the strong 3-dimensional eddy diffusion generally associated with high speed winds prevailing in Subantarctic latitudes, a relative homogenization of the atmosphere was expected there, leading to smooth and small amplitude variations of the continental Rn-222. On the contrary it is clear that the sharp variations recorded necessitate a transport from remote continents, following a discontinuous injection.

Despite a lack of correlation between continental Rn-222 peaks and the wind speed, a good 
correlation between $\mathrm{Rn}-222$ increases on one hand, and increases of temperature and water content of the air, and low atmospheric pressures on the other hand, was often observed as shown in Fig. 4. Consequently we have been led to associate this particular type of $\mathrm{Rn}-222$ transport with synoptic scale meteorological variations. Synoptic charts relative to 1000 and 500 mbars are provided every $12 \mathrm{~h}$ by the Bureau of Meteorology of Melbourne (Australia). A given cyclonic system can be followed throughout the Subantarctic ocean around the Antarctic continent particularly in winter, as shown for example in Fig. 5.

Owing to the clockwise circulation around a South Hemisphere cyclone, it is often observed in winter that cyclonic systems pass over South Africa, which implies continental air is being drawn in towards the southeast, between warm and cold fronts (Fig. 6). Therefore continental $\mathrm{Rn}-222$ is injected from South Africa into Subantarctic areas. In the typical example shown in Fig. 6, it may be observed that 1 or 2 days after passing over South Africa, the warm sector reaches Kerguelen Island and there coincides with a sharp increase of $\mathrm{Rn}-222$ concentration up to $18 \mathrm{pCi} \cdot \mathrm{m}^{-3}$, which decreases again at the very moment when the cold front reaches the island (Fig. 7). In winter similar situations can be observed from 1 to 5 times per month at Crozet

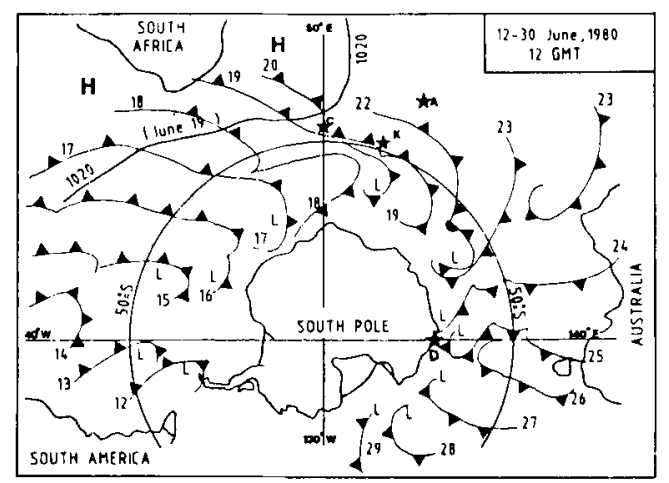

Fig. 5. Daily position of a front moving from South America to Indian and then to Pacific oceans. Numbers from 12 to 29 give the corresponding dates in June 1980. The $1020 \mathrm{mb}$ isobar is shown for June 19. A : Amsterdam Island, $\mathrm{C}$ : Crozet Island. $\mathrm{K}$ : Kerguelen Island, D: Dumont d'Urville (Terre Adélie). and Kerguelen Island, and more rarely at Amsterdam Island.

A second type of meteorological situation can also produce $\mathrm{Rn}-222$ injection into the Subantarctic marine atmosphere. In Fig. 8 a strong barrier, due to high pressure, prevented the fronts from passing over South Africa. However the continental air, highly concentrated in Rn-222, was drawn in from South America from June 27 to 291980 . The cyclonic system reached Crozet Island on July 2, Kerguelen Island on July 3 and Amsterdam Island on July 4. As observed in Fig. 9, the passage of the system past the station also coincided here with sharp increases and then decreases of the Rn-222 concentration. In contrast, whenever a depressionary system did not touch any continent (Fig. 10), the passage of the fronts past a station did not give significant Rn222 variations (Fig. 11). Such a situation was observed for 25 days in July 1980 (Fig. 12), resulting in a mean monthly value reduced by $40 \%$ relative to the usual value (see Table 1 ).

In summer, the westerlies are shifted towards the south and the continental air is no longer drawn in, except on rare occasions. Consequently, most of the $R n-222$ peaks observed in summer can actually be correlated with $\mathrm{Rn}-220$ maxima, both being of local origin. Despite the higher frequency of low speed winds in summer, which gives a higher Rn-220 mean monthly concentration (see Fig. 13), this season is characterized by particularly low $\mathrm{Rn}-222$ mean monthly values. This seasonal variation, which agrees with the preceding analysis, shows that discontinuous advection in the lower troposphere seems to be a prevalent process for supplying continental materials to the Subantaretic atmosphere. Lockhart (1962) found similar seasonal variations at Kodiak and Wales (Alaska) with a deep minimum of $R n-220$ in winter, likely due to the local frozen soil and simultaneously a Rn-222 maximum, which could be ascribed to long-range transport from mid-latitude continental areas.

\section{Transit time and dilution}

It is possible from synoptic charts series to obtain a value for the time lag between the passage of a warm sector over South America and the Subantarctic stations (see Fig. 8). Typical 

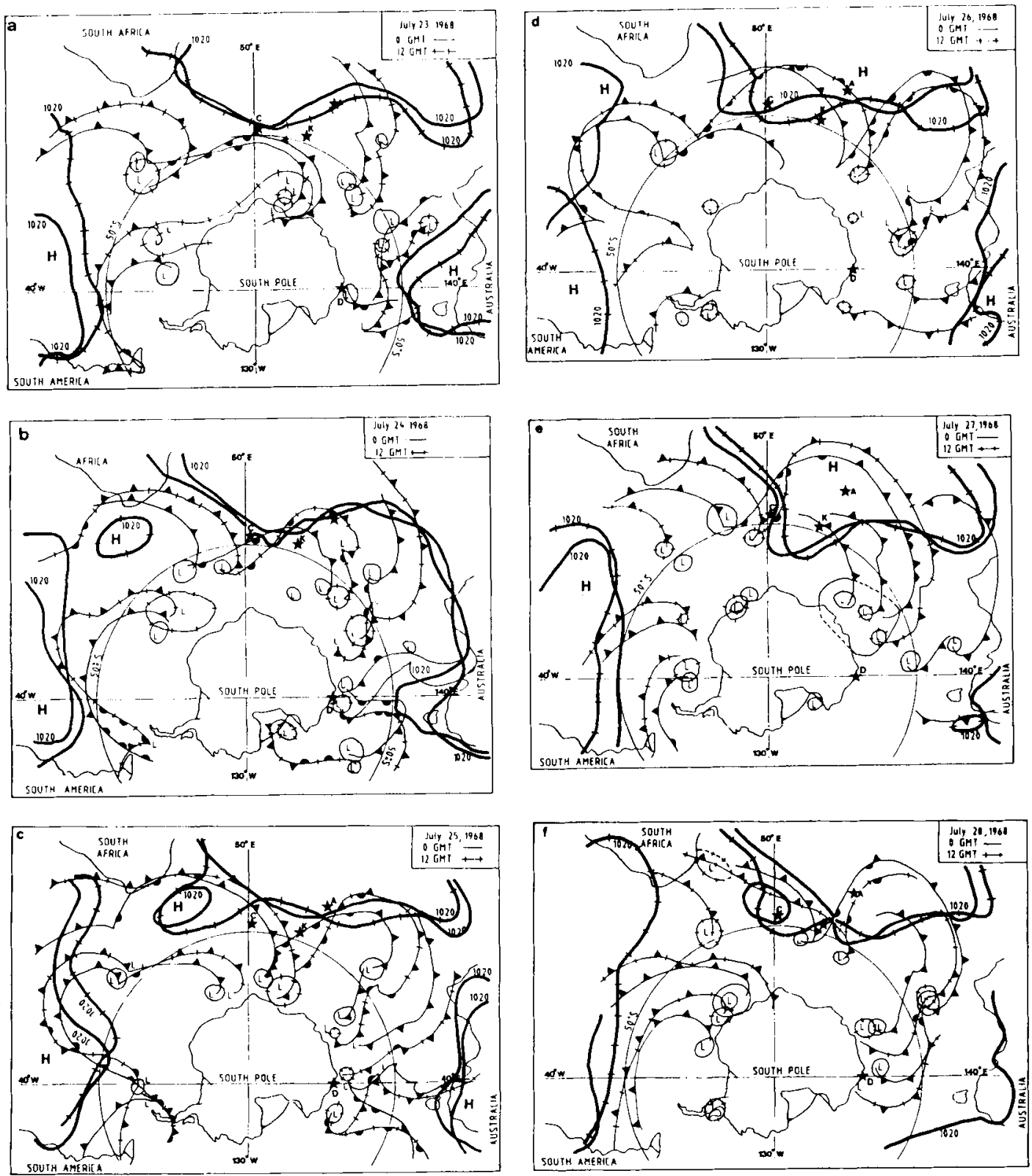

Fig. 6. Cyclones over South Africa and Subantarctic islands from July 23 to 28,1968 . Cold and warm fronts are indicated as well as the $1020 \mathrm{mb}$ isobar. A: Amsterdam Island, C: Crozet Island. K: Kerguelen Island, D : Dumont d'Urville (Terre Adélie).

results are shown in Table 2 which imply mean travel speeds of the order of 60 to $70 \mathrm{~km} \cdot \mathrm{h}^{-1}$, which are in agreement with normal conditions in the roaring fourties. The same evaluation cannot be made for air mass transport from South Africa to Subantarctic stations since the meteorological fronts are slanted relatively to the meridians with a variable slope (see Fig. 5). However, a 
cross-correlation between the radonic storms recorded at Crozet and Kerguelen Island gives a mean transit time of about $22 \mathrm{~h}$ between these stations, corresponding to a mean speed of 68

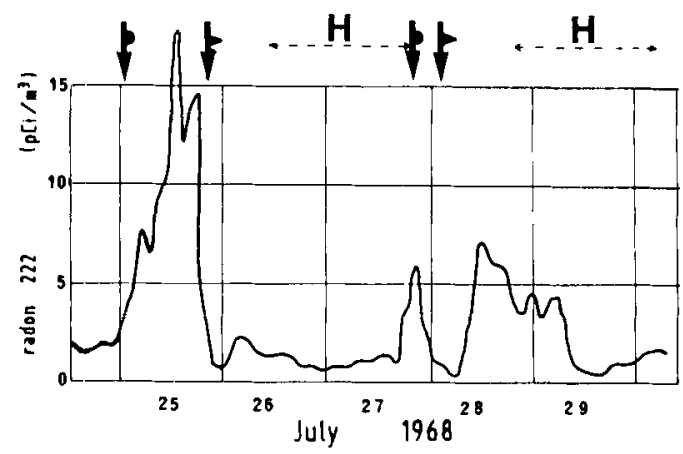

Fig. 7. High peak of Rn-222 observed at Kerguelen Island on July 251968 . Warm front passage over the station. $\mathbf{F}$ : Cold front passage over the station. $\mathbf{H}$ : High pressure.

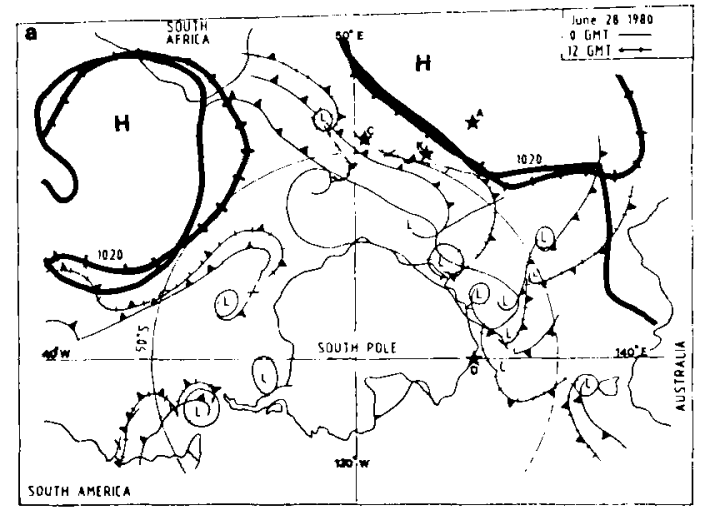

$\mathrm{km} \cdot \mathrm{h}^{-1}$, in good agreement with the mean speed in Table 2. From this last value of $70 \mathrm{~km} \cdot \mathrm{h}^{-1}$, we calculated the mean transit times between South Africa and the Subantarctic stations indicated in Table 3, together with the range of values corresponding to extreme speeds of 52 and 83 $\mathrm{km} \cdot \mathrm{h}^{-1}$.

Knowledge of the transit time between the continental source of Rn-222 and the Subantarctic stations permits the calculation of the radioactive decay of this nuclide during transport. Consequently, the comparison between the continental Rn-222 concentration and the concentration actually measured at a station, after decay correction, should give the dilution factor of the continental air mass during the advection process. Unfortunately, the Rn-222 initial content of the air mass over the continent is generally unknown. However, it may be pointed out that most of the variations of $\mathrm{Rn}-222 \mathrm{ob}-$ served over continents at ground level are mainly

Fig. 8. Cyclones from South America to East Indian ocean. The high pressures $(\mathrm{H})$ prevent the cyclones from passing over South Africa from June 28 to July 2. Fronts and $1020 \mathrm{mb}$ isobar are indicated. A : Amsterdam Island, C: Crozet Island. K: Kerguelen Island, D : Dumont d'Urville (Terre Adélie).

Table 1. Radon deficit in the 3 austral stations during winter 1980

\begin{tabular}{|c|c|c|c|c|c|c|c|c|c|}
\hline \multirow[b]{2}{*}{ Stations } & \multicolumn{2}{|l|}{$\begin{array}{l}\text { June } \\
\left(\mathrm{pCi} / \mathrm{m}^{3}\right)\end{array}$} & \multicolumn{3}{|c|}{$\begin{array}{l}\text { July } \\
\left(\mathrm{pCi} / \mathrm{m}^{3}\right)\end{array}$} & \multicolumn{2}{|c|}{$\begin{array}{l}\text { August } \\
\left(\mathrm{pCi} / \mathrm{m}^{3}\right)\end{array}$} & \multicolumn{2}{|c|}{$\begin{array}{l}\text { September } \\
\left(\mathrm{pCi} / \mathrm{m}^{3}\right)\end{array}$} \\
\hline & average & 1980 & average & 1980 & $*$ & average & 1980 & average & 1980 \\
\hline Crozet & 2.3 & 1.85 & 2.0 & 1.25 & 0.7 & 1.6 & 1.35 & 1.3 & 1.0 \\
\hline Kerguelen & 1.5 & 1.4 & 1.55 & 0.9 & 0.8 & 1.35 & 0.9 & 1.1 & 0.95 \\
\hline Amsterdam & 1.6 & 1.65 & 1.6 & 1.45 & 1.1 & 1.35 & 1.2 & 1.1 & 0.7 \\
\hline
\end{tabular}

* July 1980 calculated without the 3 days $(28,29,30)$ during which the anticyclonic barrier was widely open.

Tellus 38B (1986), 3-4 
due to changes in the vertical eddy diffusion, when the total amount of this nuclide between 0 and $2 \mathrm{~km}$ height is rather constant in time and from place to place (Lambert et al., 1982). These authors showed that the mean equivalent concentration of $\mathrm{Rn}-222$ in this layer is about 80

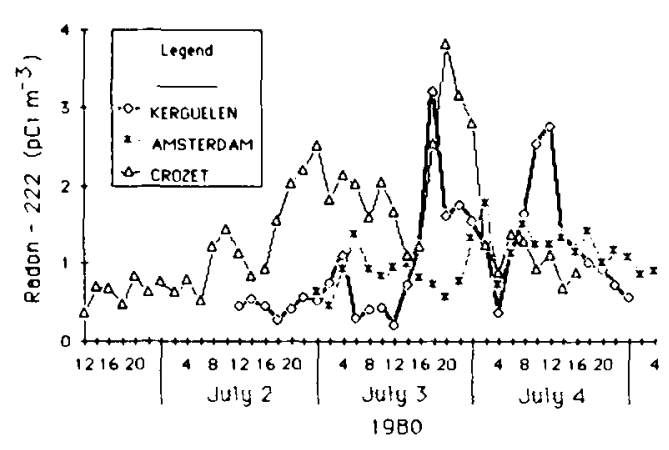

Fig. 9. Rn-222 peaks observed at Crozet and Kerguelen Islands on July 3 . The corresponding synoptic charts are shown in Fig. 8.
$\mathrm{pCi} \cdot \mathrm{m}^{-3}$ (for a typical concentration of 125 $\mathrm{pCi} \cdot \mathrm{m}^{-3}$ at ground level). We can therefore calculate the dilution factor, for each radonic storm observed, by the expression:

$$
d=\frac{80}{c} \exp (-\lambda t)
$$

where $d$ is the dilution factor, $c$ the maximum $\mathrm{Rn}-222$ concentration measured, $\lambda$ the $\mathrm{Rn}-222$ radioactive constant, and $t$ the transit time corresponding to this peak.

The results are shown in Table 4 . It is worth noting that in these calculations, we assumed that the vertical distribution of the $\mathrm{Rn}-222$ was approximately homogeneous over the Subantarctic stations. The high values obtained for the injections from South America are due to the long distance travelled by the air masses. These values are slightly overestimated due to the narrowness of South America, south of $40^{\circ} \mathrm{S}$, which prevents $\mathrm{Rn}-222$ from reaching its continental equilibrium concentration.
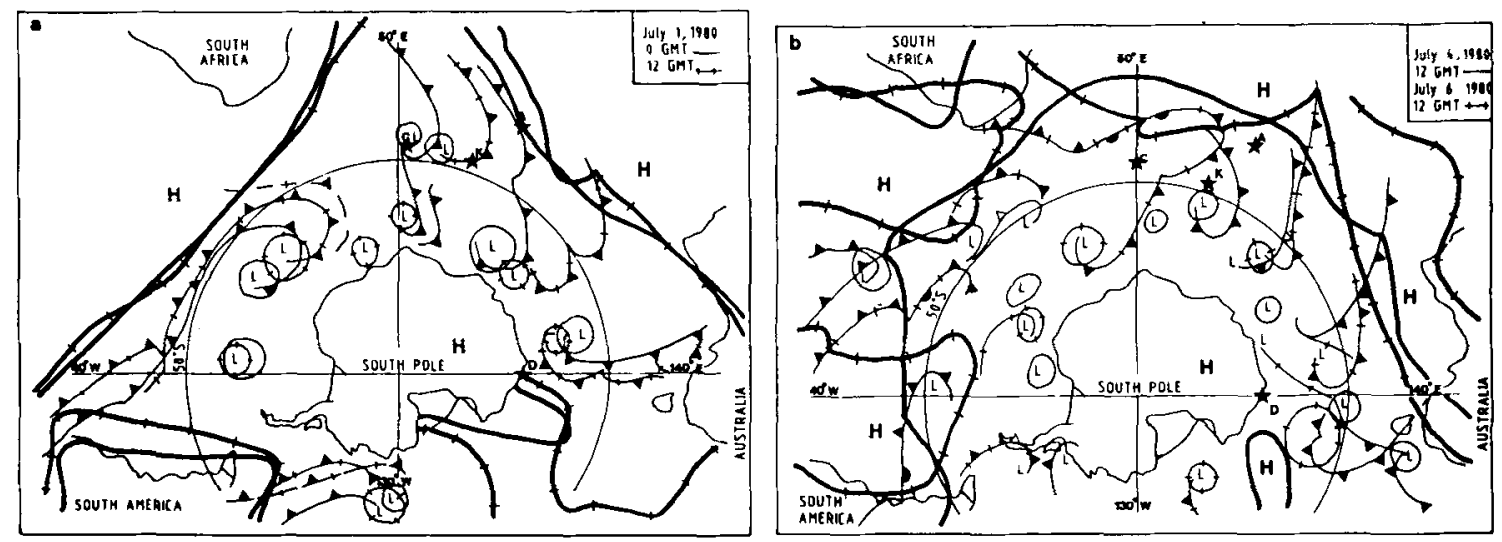

Fig. 10. Example of purely oceanic fronts circulation from July 1 to 61980 . The thick lines correspond to the 1020 mb isobar. A: Amsterdam Island, C: Crozet Island. K: Kerguelen Island, D: Dumont d'Urville (Terre Adélie).

Table 2. Transit times between South America, Subantarctic Islands and the longitude of Dumont d'Urville (Antarctica)

\begin{tabular}{lllll}
\hline & & \multicolumn{2}{l}{ Transit times (days) } & \\
$\begin{array}{llll}\text { From South } \\
\text { America to }\end{array}$ & $\begin{array}{l}\text { Distance } \\
(\mathrm{km})\end{array}$ & average & range & $\begin{array}{l}\text { Mean speed } \\
\left(\mathrm{km} \mathrm{h}^{-1}\right)\end{array}$ \\
\hline Crozet & $\approx 10,000$ & 5.9 & $5-8$ & 70 \\
Kerguelen & $\approx 11,500$ & 6.8 & $6-9$ & 70.8 \\
Meridian $140^{\circ} \mathrm{E}$ & $\approx 16,000$ & 10.7 & $9-12.5$ & 62.4 \\
\hline
\end{tabular}




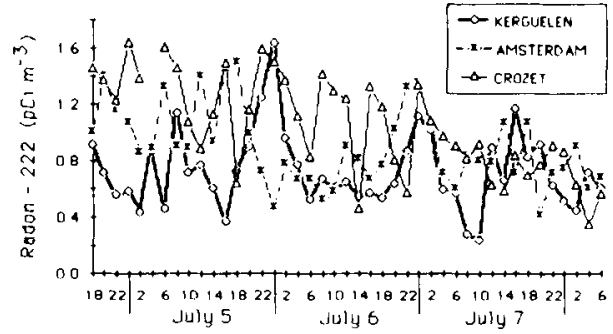

Fig. 11. Rn-222 concentration recorded at 3 stations from July 4 to 81980 , and showing only low figures. The corresponding synoptic charts are shown in Fig. 10.

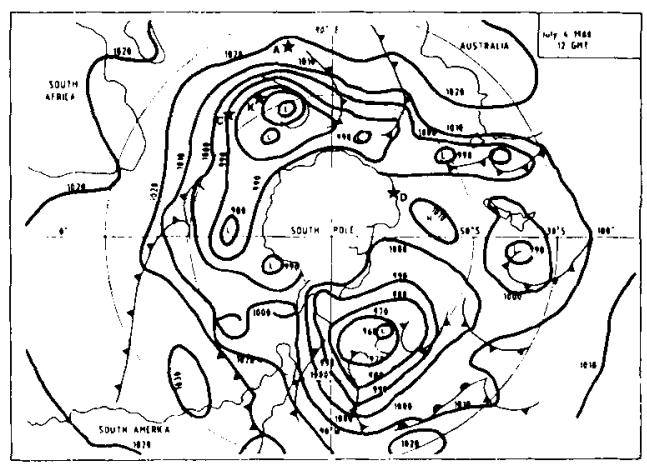

Fig. I2. Typical synoptic chart observed in July 1980 . The $1020 \mathrm{mb}$ isobar prevents cyclones from passing over continents. A: Amsterdam Island, C: Crozet Island. K: Kerguelen Island, D: Dumont d'Urville (Terre Adélie).

Table 3. Transit times between South Africa and Subantarctic Islands

\begin{tabular}{llll}
\hline & & \multicolumn{2}{l}{ Transit times (days) } \\
\cline { 3 - 4 } $\begin{array}{lll}\text { From South } \\
\text { Africa to }\end{array}$ & $\begin{array}{l}\text { Distance } \\
(\mathrm{km})\end{array}$ & average & range \\
\hline Crozet & $\approx 2,800$ & 1.7 & $1.4-2.2$ \\
Kerguelen & $\approx 4,200$ & 2.5 & $2.1-3.4$ \\
Amsterdam & $\approx 5,000$ & 3 & $2.5-4$ \\
\hline
\end{tabular}

\section{Radon transport to the Antarctic east coast}

Rn-222 and 220 have also been monitored since 1960 at the French station Dumont d'Urville (Terre Adelie) on the east coast of the
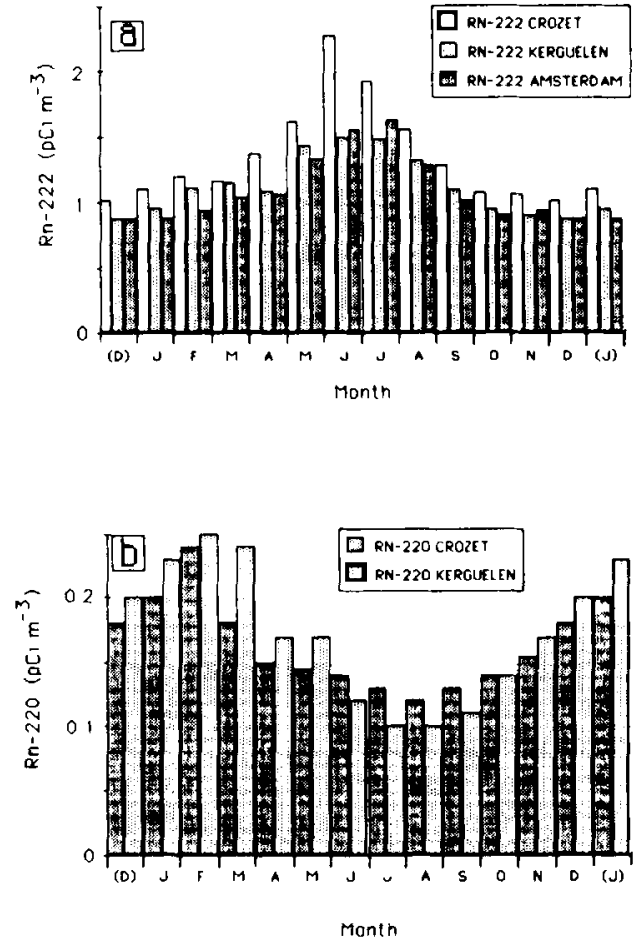

Fig. 13. Seasonal variations of (a) $\mathrm{Rn}-222$ at Crozet, Kerguelen, and Amsterdam islands, and (b) Rn-220 at Crozet and Kerguelen Islands.

Antarctic continent (see Fig. 1). Because almost all this continent is ice covered, there is practically no local emission of these nuclides into the atmosphere. This is particularly notable for $\mathrm{Rn}$ 220 whose concentration is very low, generally less than our detection limit of $0.01 \mathrm{pCi} \cdot \mathrm{m}^{-3}$. Consequently the Rn-222 measured at Dumont d'Urville can be considered as transported there from remote continental sources.

Radonic storms were observed at Dumont d'Urville, very similar to those of the Subantarctic stations (Polian and Lambert, 1968). In winter, some of these radonic storms occurred in the same meteorological conditions as previously described, that is when a warm sector having passed over Australia arrived in the vicinity of the station (see Fig. 14). During the winter months, from March to October, the Rn-222 mean concentration at Dumont d'Urville is of the order of $0.65 \mathrm{pCi} \cdot \mathrm{m}^{-3}$ (Fig. 15), which is lower than in subantarctic areas $\left(1.4\right.$ to $\left.2.3 \mathrm{pCi} \cdot \mathrm{m}^{-3}\right)$. 
Table 4. Dilution rates between southern continents and subantarctic islands

\begin{tabular}{lccccc}
\hline & \multicolumn{2}{c}{ From South Africa } & & \multicolumn{2}{c}{ From South America } \\
\cline { 2 - 3 } \cline { 5 - 5 } Stations & mean & range & & mean & range \\
\hline Crozet & 3 & $1.5-9$ & 7.3 & $3-14.3$ \\
Kerguelen & 6 & $3-19$ & 7.4 & $3.5-15$ \\
Amsterdam & 5 & $3-17$ & 7.2 & $4.7-13.3$ \\
\hline
\end{tabular}

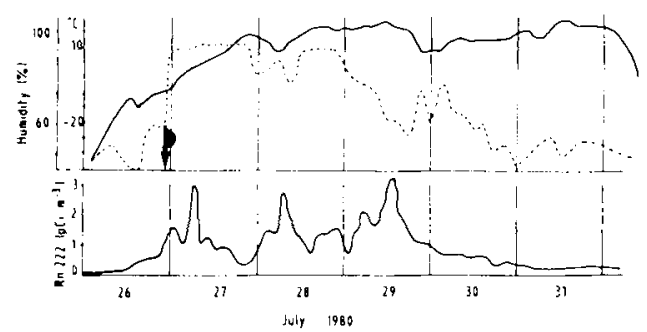

Fig. 14. Example of records of Rn-222, air temperature and relative humidity at Dumont d'Urville (Terre Adélie Antarctica). W Warm front passage near by the station (at North). Humidity.

These values agree with the general pattern of an advective transport through the lower troposphere. In contrast, the mean monthly concentration of Rn-222 is particularly high in summer at Dumont d'Urville. Therefore the seasonal variations are exactly in opposition between the Subantarctic areas and the east Antarctic coast.

The $\mathrm{Rn}-222$ mean concentration in summer is of the order of $1.8 \mathrm{pCi} \cdot \mathrm{m}^{-3}$ at Dumont d'Urville (Fig. 15) instead of the $1 \mathrm{pCi} \cdot \mathrm{m}^{-3}$ found in Subantarctic areas at the same time. These values, higher on the Antarctic coast than in Subantarctic latitudes, are confirmed by the latitudinal profiles of $\mathrm{Rn}-222$ obtained on board ships between Hobart (Tasmania) and Dumont d'Urville. Fig. 16 shows the concentrations measured in December, from 1963 to 1966 . This is in agreement with Wilgain et al. (1968). Such observations rule out the possibility of southwards transports of this nuclide at sea level. The summer maximum at Dumont d'Urville is not accounted for either by air circulation around or across the Antarctic continent because at most of the Antarctic stations the values measured are

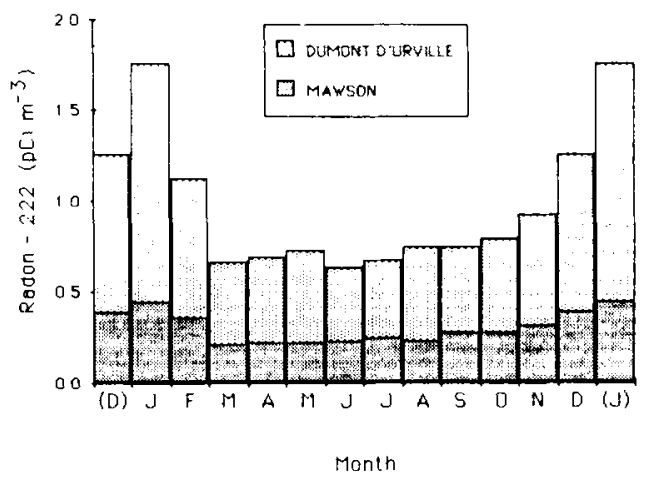

Fig. 15. Rn-222 seasonal variations at Dumont d'Urville (Terre Adélie Antarctica) and Mawson (Antarctica).

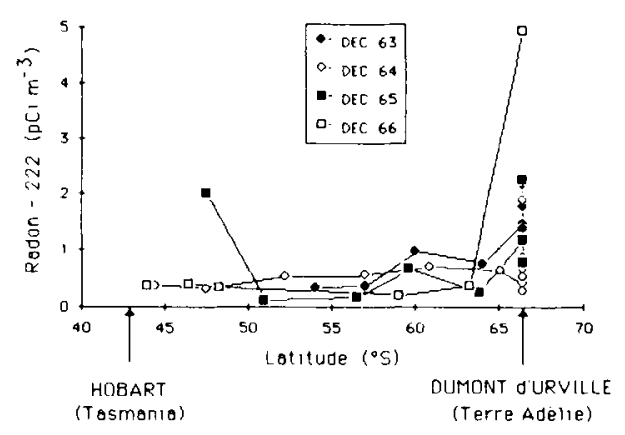

Fig. 16. Rn-222 latitudinal profile at sea level between Hobart Tasmania (Australia) and Dumont d'Urville (Terre Adélie Antarctica).

significantly lower: 0.4 to $0.5 \mathrm{pCi} \cdot \mathrm{m}^{-3}$ at Mawson where the seasonal variations are however identical to those of Dumont d'Urville (Fig. 15) and 0.6 at Molodejnaya (Polian, 1984); 0.25 at Roi Beaudouin (Wilgain et al., 1968); 0.4 at the South Pole (Lockhart et al., 1966). In fact, 


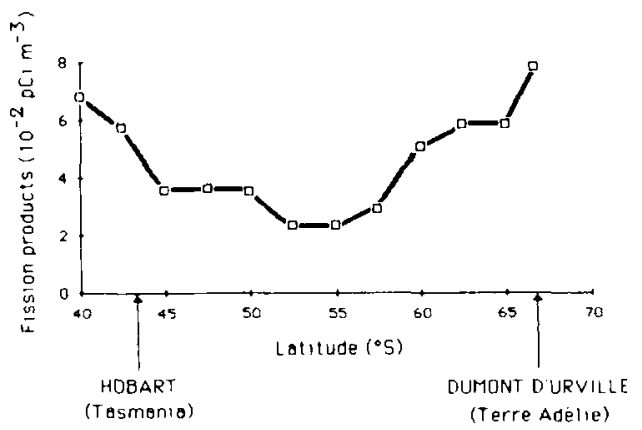

Fig. 17. Fission products latitudinal profile at sea level between Tasmania (Australia) and Terre Adélie (Antarctica). Average of 4 profiles from December 1963 to 1966 .

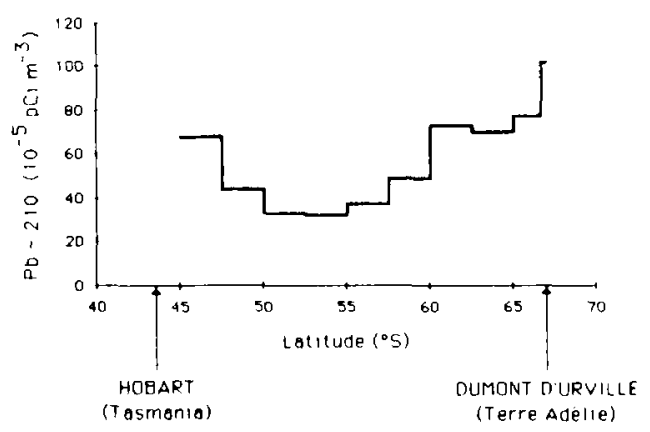

Fig. 18. Mean Pb-210 latitudinal profile at sea level between Tasmania (Australia) and Terre Adélie (Antarctica).

similar observations can be made about the latitudinal repartition of fission products and $\mathrm{Pb}-210$ as shown in Figs. 17 and 18, also confirmed by Lambert et al. (1965) and Sanak (1983).

Sanak et al. (1985) have deduced from the study of cosmogenic nuclides (Be-7 and P-32) that the stratosphere-troposphere exchange is particularly important over the Antarctic coast. Since the $\mathrm{Rn}-222$ cannot be transported through the stratosphere due to its short half-life, it seems likely that the high concentrations of $\mathrm{Rn}-222$ at Dumont d'Urville result from the strong summer convection over the southern continents followed by southward advection in the mid, and/or possibly upper troposphere and by subsidence over Antarctica. This idea was already suggested by Hogan et al. (1982) working on total aerosols and Aitken nuclei over the South Pole, and agrees

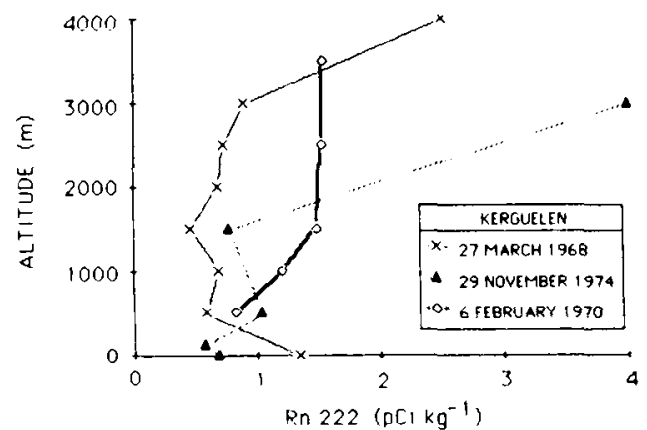

Fig. 19. Vertical profiles of Rn-222 above Kerguelen Islands.

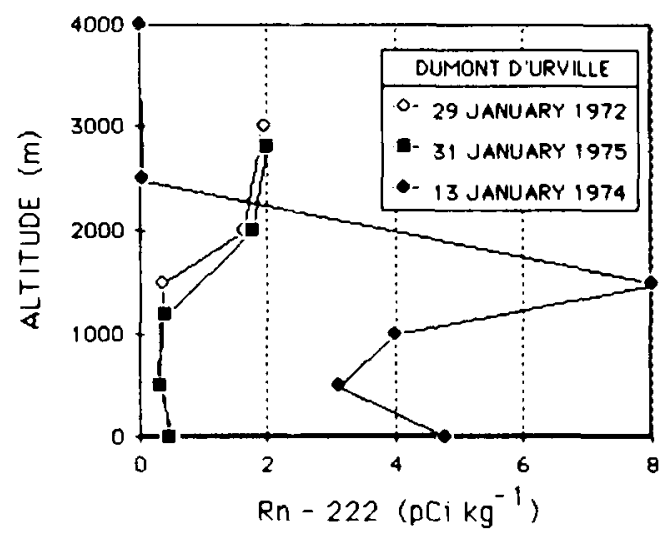

Fig. 20. Vertical profiles of Rn-222 above Dumont d'Urville (Terre Adélie Antarctica).

with the $\mathrm{CO}_{2}$ air borne measurements of Bischof (personal communication, 1985). Such an interpretation is supported by the vertical profiles of Rn-222 over Kerguelen Island and Dumont d'Urville shown in Figs. 19 and 20 where a concentration maximum is frequently observed at altitudes from 1 to more than $3 \mathrm{~km}$. This conclusion is in agreement with Liu et al. (1984) who analysed $\mathrm{Rn}-222$ vertical profiles obtained in May and August above the American continent by Moore et al. (1973).

\section{Conclusion}

The study of Rn-222 and 220 has shown, at least in Subantarctic areas, the existence of continental air mass advection, in the lower layer of 
the troposphere, which is related to the warm sector of cyclonic systems. During these well individualized events, all of the atmospheric tracers present in the continental air are transported over thousands of kilometers above the oceans with little dilution, generally less than a factor 10. Their concentration in the air mass concerned is, therefore, essentially limited by their own specific removal process. In the case of $\mathrm{Rn}-222$, it is only removed by radioactive decay with a mean life of 5.5 days. The concentration at a given station of an atmospheric trace constituent for which sources, sinks and life time would be similar to those of Rn-222 may be calculated from its continental value by using, with minor adjustments, the ratio of the $\mathrm{Rn}-222$ concentrations over continents and at the station. That is particularly the case for submicronic aerosols as well as various gaseous species such as propane.

The existence in Subantarctic latitudes of a clear maximum of $\mathrm{Rn}-222$ in summer shows that, on the whole, these low altitude advections are the major process of injection of continental materials at these latitudes. However this process seems to be less active in bringing continental materials to Antarctica. In this case, the transport of continental materials results mainly from advections which occur in the mid and/or upper part of the troposphere particularly in December and January. During the summer season, and at the latitude of the Antarctic coast, the meridian transfer, as detected at sea level, is northward instead of the southward shift generally accepted. This observation could account for the delay and the fading observed at Subantarctic stations relative to Antarctic ones in the variations of very different atmospheric tracers as fission products or $\mathrm{CO}_{2}$.

\section{Appendix}

Far enough from the continental sources, it can be assumed that $\mathrm{Rn}-222$ and 220 are in radioactive equilibrium with their short-lived decay products. These are present in the air as aerosols and can be sampled by filtration. The filter utilized (Poelmann Schneider blue) is a large circular filter fixed on a rotating disc. Every other hour, the part of the filter that has been collecting the aerosols is automatically switched over to an alpha scintillation counter. The alpha measurements give a very low background of 2 counts/ $h$. These are practically specific for Radon daughters. However, the counting efficiency of the filter, which is not a thin source of alpha rays, is determined relative to a beta counting, by comparing the alpha and beta activities of $R n-222$ short-lived daughters in radioactive equilibrium collected on the same kind of filter. This alpha counting efficiency is about $25 \%$. It is reproducible within $2 \%$. With an air flow of $12 \mathrm{~m}^{3} \cdot \mathrm{h}^{-1}$, the detection limit is as low as $0.01 \mathrm{pCi} \cdot \mathrm{m}^{-3}$.

\section{Acknowledgements}

The authors are very grateful to all the teams which have participated in the sampling and measuring in the Antarctic and Subantarctic stations. This study has been supported by CNRS, CEA, and the administration of the "Terres Australes et Antarctiques Françaises".

\section{REFERENCES}

Broecker, W. S., Li, Y. H. and Cromwell, J. 1967. Radium 226 and Radon 222; concentration in Atlantic and Pacific oceans. Science 158, 1307-1310.

Danielsen, E. F. 1961. Trajectories: isobaric, isentropic and actual. J. Meteorol. 18, 479-486.

Fontan, J., Blanc, D., Bouville, A. and Lambert, G. 1962. Measurement of the natural radioactivity of the air above Atlantic ocean (in French). J. Mec. Phys. Atmos., Paris, II, 15, 107-113.

Hoang, C. T. and Servant, J. 1972. Radon flux from the sea (in French). C. r. Acad. Sci. Paris 274, 3157-3160.

Hogan, A., Barnard, S., Samson, J. and Winters, W.
1982. The transport of heat, water vapor and particulate material to the South polar plateau. $J$. Geophys. Res. 87, C6, 4287-4292.

Lambert G. and Polian, G. 1963. Diffusion of continental and oceanic air masses at low altitude in both hemispheres (in French). C. r. Acad. Sci. Paris 256, 4265-4267.

Lambert, G., Labeyrie, J. and Ardouin, B. 1965. Existence of a zonal structure of the low atmosphere especially in the southern hemisphere (in French). $C$. r. Acad. Sci. Paris 261, 3857-3860.

Lambert, G., Polian, G, and Taupin, D. 1970. Exis- 
tence of periodicity in radon concentrations and in large scale circulation at lower altitude between 40 and $70^{\circ} \mathrm{S}$. J. Geophys. Res. 75, 234 I-2345.

Lambert, G., Ardouin, B., Polian, G. and Sanak, J. 1972. Natural radioactivity balance in the atmosphere of southern hemisphere Natural Radiation Environment 2, U.S. Energy Research and Development Administration conf. 720805 P2, 787-807.

Lambert, G., Polian, G., Sanak, J., Ardouin, B., Buisson, A., Jegou, A. and Le Roulley, J. C. 1982. Radon and daughter products cycle: application to troposphere-stratosphere exchanges (in French). Ann. Géophys. 38, 4, 497-531.

Larson, R. E., Lamontagne, R. A., Wilkniss, P. E. and Wittmann, W. I. 1972. Radon 222, $\mathrm{CO}, \mathrm{CH}$ and continental dusts over Greenland and Norwegian sea. Nature 240, 345-347.

Larson, R. E. and Bressan, D. J. 1978. Radon 222 as an indicator of continental air masses and air mass boundaries over ocean areas. Natural Radiation Environment III, U.S. Department of Energy conf. 780422, 308-325.

Liu, S. C., Mc Afee, J. R. and Cicerone, R. J. 1984. Radon 222 and tropospheric vertical transport $J$. Geophys. Res. 89, D5, 7291-7297.

Lockhart, L. B. Jr. 1962. Natural radioactive isotopes in the atmosphere at Kodiak and Wales, Alaska. Tellus 14, 350-355.

Lockhart, L. B. Jr., Patterson, R. L. and Saunders, A. W. 1966. Airborne radioactivity in Antarctica. J. Geophys. Res. 71, 1985-1991.

Moore, H. E., Poet, S. E. and Martell, E. A. 1973. Rn222, $\mathrm{Pb}-210, \mathrm{Bi}-210$ and $\mathrm{Po}-210$ profiles and aerosol residence times versus altitude. J. Geophys. Res. 78 , 7065-7075.

Nguyen, B. C., Lambert, G., Polian, G. and Jacquin, J. P. 1967. Comparison of the vertical distributions of Rn-222 above Atlantic ocean, antarctica and Paris area (in French). C. r. Acad. Sci. Paris 265, 10651068.

Nguyen, B. C., Bonsang, B., Lambert, G. and Pasquier,
J. L. 1975. Residence time of sulfur dioxyde in the marine atmosphere. Pure Appl. Geophys. 123, 489500.

Petersen, R. A. and Uccellini, L. W. 1979. The computation of isentropic atmospheric trajectories using a discrete model formulation. Mon. Wea. Rev. 107, 566-574.

Polian, G. and Lambert, G. 1968. Radonic storms in Terre Adelie (Antarctica) (in French). Coll. Electron. Nucl. et Radioprotec., Toulouse, France

Polian, G. 1984. Atmospheric transports in southern Hemisphere, and global balance of $\mathrm{Rn}-222$ (in French). Ph.D. Thesis, Univ. P. M. Curie, Paris 6, France.

Rangarajan, C., Subramian, S. K. and Eapen, C. D. 1979. A synoptic study of the variations in radon activity over the Arabian sea and the bay of Bengal region during the monsoon period 77. Arch. Meteorol. Geophys. Biokim. A 28, 361-374.

Sanak, J. 1983. Origin and transport of aerosols in Antarctica (in French). Ph.D. thesis, Univ. Picardie, St. Quentin, France.

Sanak, J., Lambert, G. and Ardouin, B. 1985. Measurement of stratosphere-to-troposphere exchanges in Antarctica by using short-lived cosmonuclides. Tellus 37B, 109-115.

Turekian, K. K., Nozaki, Y. and Benninger, L. K 1977. Geochemistry of atmospheric radon and radon products. Ann. Rev. Earth Planet. Sci. 5, 227-255.

Wilgain, S., Picciotto, E., Deschamps, J. and Ketelers, R. 1968. Belgo-Neerlandaises Antarctic expeditions in 1964 and 1965 : atmospheric radioactivity (in French). Exantar ed., Brussels, Belgium.

Wilkening, M. H. and Clements, W. E. 1975. Radon 222 from the ocean surface. J. Geophys. Res. 80 , 3828-3830.

Wilkniss, P. E., Larson, R. E. and Bressan, D. J. 1974. Atmospheric radon and continental dust near the Antarctic and their correlation with air mass trajectories computed from Nimbus 5 satellite photographs. J. Appl. Meteorol. 13, 512-515. 